\title{
Evidence of Systemic Responses to Viral Pathogens using Malondialdehyde, Tumor Necrosis Factor Alpha and Superoxide Dismutase
}

\author{
Mathew Folaranmi Olaniyan ${ }^{1, *}$, Tolulope Busayo Ojediran ${ }^{1}$, Gbenga Shedrack Olayinka ${ }^{2}$
}

\section{Mathew Folaranmi Olaniyan ${ }^{1, *}$, Tolulope Busayo Ojediran ${ }^{1}$, Gbenga Shedrack Olayinka²}

'Department of Medical Laboratory Science, Edo University lyamho, NIGERIA.

${ }^{2}$ Department of Medical Laboratory Science, Achievers University, Owo, NIGERIA.

\section{*Correspondence}

\section{Dr. Mathew Folaranmi Olaniyan} Department of Medical Laboratory Science, Edo University lyamho, NIGERIA.

Phone: +2348052248019

Email: olaniyanmat@yahoo.com

\section{History}

- Submission Date: 28-12-2019;

- Review completed: 24-02-2020;

- Accepted Date: 23-03-2020.

DOI : 10.5530/ijcep.2020.7.1.5

Article Available online

http://www.ijcep.org

Copyright

(C) 2020 Phcog.Net. This is an openaccess article distributed under the terms of the Creative Commons Attribution 4.0 International license.

\begin{abstract}
Background and Aim: Infectious agents are triggers of oxidative stress and inflammation. This work was designed to determine evidence of systemic responses to viral pathogens using malondialdehyde, tumor necrosis factor alpha and superoxide dismutase. Methods: The subjects recruited for this study include $23 \mathrm{HCV}$ mono-infected volunteers (aged 24-67 years; Male-10; Female-13), 30 HBV mono-infected volunteers (aged 24-67 years; Male-15; Female-15), 18 HIV mono-infected volunteers (aged 24-67 years; Male-8; Female-10), 23 Viral (HCV, HIV, HBV) Co-infected volunteers (aged 24-67 years; Male-10; Female-13) and 50 age matched control volunteers who were not infected with HCV, HIV or HBV (Female-25; Male-25). Subjects tested negative to Acid Fast Bacilli (AFB) and Plasmodium tests were recruited. Test subjects who have not initiated antiviral therapy were recruited for the study. Five milliliters of venous blood was obtained from each of the subjects into lithium heparinized bottles for the assay of HCV, HIV, HBV, TNF $\alpha$ by ELISA, SOD, MDA by Colorimetry, Giemsa thick blood film staining for plasmodium while sputum samples were obtained from each of the subjects for Ziehl Neelsen staining for Acid Fast Bacilli(AFB). Results: There was a significant increase in plasma MDA and TNF $\alpha$ in patients with viral co-infection compared with control and patients with mono-infections of HCV, HBV and HIV $(p<0.05)$. There was a significant decrease in plasma SOD in patients with viral co-infection compared with control and patients with mono-infection of HBV $(p<0.05$; Table 1, 2; Figure 1, 2). The result also showed a significantly lower plasma SOD in patients with viral co-infection, mono-infection of HIV, HCV and HBV than the results obtained in the control subjects $(p<0.05)$. There was a significant increase in plasma TNF- $\alpha$ in patients with viral co-infection compared with control and patients with mono-infections of HCV, HIV and HBV $(p<0.05)$. The result also showed a significantly higher plasma TNF- $\alpha$ in patients with viral co-infection, mono-infection of HIV, $\mathrm{HCV}$ and HBV than the results obtained in the control subjects $(p<0.05)$. Conclusion: The work revealed a significant evidence of systemic responses to viral pathogens as indicated by increased plasma malondialdehyde, tumor necrosis factor alpha and decreased plasma superoxide dismutase in viral mono and coinfections.
\end{abstract}

Key words: Systemic Response, HCV, HIV, HBV, Malondialdehyde, Tumor Necrosis Factor Alpha, Superoxide Dismutase.

\section{INTRODUCTION}

The immune system makes use of the germicidal properties of oxidants by producing oxidizing species to kill infectious pathogens. This mechanism involves the activation of phagocytes to produce reactive oxygen species (ROS) and reactive nitrogen species which include superoxide $\left(\cdot \mathrm{O}^{-2}\right)$, nitric oxide $(\bullet \mathrm{NO})$ and their particularly reactive product, peroxynitrite $\left(\mathrm{ONOO}^{-}\right){ }^{\left[{ }^{[1]}\right.}$ Malondialdehyde occurs naturally and is a marker for oxidative stress. ${ }^{[2]}$ Oxidative stress is an imbalance between the systemic manifestation of reactive oxygen species and a biological system's ability to readily detoxify the reactive intermediates or to repair the resulting damage. ${ }^{[3,4]}$ Disturbances in the normal redox state of cells can bring about toxic effects through the production of peroxides and free radicals that can damage all components of the cell, such as proteins, lipids including pathogens. ${ }^{[3]}$ Superoxide dismutase is an enzyme that alternately catalyzes the dismutation (or partitioning) of the superoxide $\left(\mathrm{O}^{2-}\right)$ radical into either ordinary molecular oxygen $\left(\mathrm{O}_{2}\right)$ or hydrogen peroxide $\left(\mathrm{H}_{2} \mathrm{O}_{2}\right)$ to prevent cellular damage. Superoxide is produced as a by-product of oxygen metabolism that can cause many types of cell damage. ${ }^{[4]}$

Tumor necrosis factor alpha or TNFa is a proinflammatory or inflammatory cytokine in systemic inflammation that regulates the immune cells and one of the cytokines of acute phase reaction. It is
Cite this article: Olaniyan MF, Ojediran TB, Olayinka GS. Evidence of Systemic Responses to Viral Pathogens using Malondialdehyde, Tumor Necrosis Factor Alpha and Superoxide Dismutase. Int J Clin Exp Physiol. 2020;7(1):18-21. 
produced by activated macrophages, CD4+ lymphocytes, NK cells, neutrophils, mast cells, eosinophils and neurons. ${ }^{[5]}$ It induces fever, apoptotic cell death, cachexia, inflammation and inhibits tumorigenesis and viral replication. ${ }^{[6-8]}$

Viral pathogen is an infectious agent that can produce viral disease. Viruses are particles with very small size of between 20 and 300 nanometers in length containing RNA or DNA. Viruses only replicate in a host cell. Some of the diseases that are caused by viral pathogens include smallpox, influenza, mumps, measles, chickenpox, ebola, HIV and rubella. Presence of viral pathogens in the body can stimulate protective immune response. ${ }^{[9]}$ Viral pathogens are mainly from the following families: Adenoviridae, Picornaviridae, Herpesviridae, Hepadnaviridae, Flaviviridae, Retroviridae, Orthomyxoviridae, Paramyxoviridae, Papovaviridae, Polyomavirus, Rhabdoviridae and Togaviridae. ${ }^{[9]}$

This work was designed to determine evidence of protective responses against viral pathogens using Malondialdehyde (MDA), tumor necrosis factor alpha (TNF- $\alpha$ ) and superoxide dismutase (SOD) to provide useful information in the investigation of viral pathogenic infections.

\section{MATERIALS AND METHODS}

\section{Study Area}

This work was carried out in in Owo a local government headquarters located in Owo/Ose Federal constituency in Ondo State South-Western part of Nigeria. The proposal of this work was reviewed and approved by the Research and Ethical Committee of Federal Medical Centre, Owo - Nigeria

\section{Study population}

The subjects recruited from Owo for this study include $23 \mathrm{HCV}$ monoinfected volunteers (aged 24-67 years; Male-10; Female-13), $30 \mathrm{HBV}$ mono-infected volunteers (aged 24-67 years; Male-15; Female-15), 18 HIV mono-infected volunteers (aged 24- 67 years; Male-8; Female-10), 23 Viral (HCV, HIV, HBV) co-infected volunteers (aged 24-67 years; Male-10; Female-13) and 50 age matched control volunteers who were not infected with HCV, HIV or HBV (Female-25; Male-25). Subjects tested negative to AFB and Plasmodium tests were recruited. Test subjects who have not initiated antiviral therapy were recruited for the study.

\section{Biological Specimen}

Five milliliters of venous blood was obtained from each of the subjects into lithium heparinized bottles for the assay of HCV, HIV, HBV, TNFa by ELISA, SOD, MDA by colorimetry, Giemsa thick blood film staining for plasmodium while sputum samples were obtained from each of the subjects for Ziehl Neelsen staining for Acid Fast Bacilli (AFB).

\section{Biological Assays}

TNF alpha ELISA

Plasma TNF alpha was determined in the subjects by ELISA using Abcam's kit.

\section{Laboratory Identification of Acid Fast Bacilli and Plasmodium spp.,}

Laboratory diagnosis of malaria was carried out by Microscopy using Ziehl Neelsen and Geimsha-Thick film methods as described by Cheesbrough. ${ }^{[10]}$

\section{Anti-HCV ELISA assay}

This was assayed using Anti-Hepatitis C Virus Core Antigen antibody Abcam kit.

\section{HIV ELISA Test}

HIV test was carried out using Genscreen ${ }^{\text {Ts }}$ ULTRA HIV Ag-Ab Biorad Kit. The Genscreen ${ }^{\mathrm{mx}}$ ULTRA HIV Ag-Ab is an enzyme immunoassay based on the principle of the sandwich technique for the detection of HIV antigen and of the various antibodies associated with HIV-1 and/or HIV-2 virus in human serum or plasma.

\section{HBsAg ELISA Test}

This was assayed using Diagnostic automation/ Cortez Diagnostics, INC kit by ELISA method

\section{Superoxide Dismutase (SOD) Activity}

This was analysed using Randox Superoxide Dismutase (Ransod) kit by Colorimetric method

\section{Malondialdehyde (MDA) Assay Kit}

This was assayed using Abcam MDA/ Lipid Peroxidation Assay Kit is designed for the rapid detection and quantitation of Malondialdehyde (MDA).

\section{Statistical Analysis of Data}

The result of this work was subjected to statistical analysis to determine student $t$-test and probability value at 0.05 level of significance.

\section{RESULTS}

The results obtained showed no significant difference in the plasma values of MDA, SOD and TNF- $\alpha$ in the results obtained in patients with viral mono-infections ( $\mathrm{p}>0.05$; Table 1, 2; Figure 1,2). There was a significant increase in plasma MDA in patients with viral co-infection compared with control and patients with mono-infections of HCV and HBV ( $p<0.05$; Table 1, 2; Figure 1,2). There was also a significant increase in plasma MDA in patients with viral co-infection, mono-infection of HIV, HCV and HBV compared with the control subjects $(p<0.05$; Table 1, 2; Figure 1,2).

There was a significant decrease in plasma SOD in patients with viral co-infection compared with control and patients with mono-infection of HBV ( $p<0.05$; Table 1, 2; Figure 1,2). The result also showed a significantly lower plasma SOD in patients with viral co-infection, mono-infection of HIV, HCV and HBV than the results obtained in the control subjects $(p<0.05$; Table1, 2; Figure 1,2). There was a significant increase in plasma TNF- $\alpha$ in patients with viral co-infection compared with control and patients with mono-infections of HCV, HIV and HBV $(p<0.05$; Table 1, 2; Figure 1,2). The result also showed a significantly higher plasma TNF- $\alpha$ in patients with viral co-infection, mono-infection of $\mathrm{HIV}, \mathrm{HCV}$ and HBV than the results obtained in the control subjects $(p<0.05$; Table 1, 2; Figure 1,2).

Table 1: Mean and Standard deviation of plasma MDA, SOD and TNF-a obtained in the subjects.

$\begin{array}{cccccc} & \begin{array}{c}\text { HCV } \\ \text { Patients }\end{array} & \begin{array}{c}\text { HBV } \\ \text { Patients }\end{array} & \begin{array}{c}\text { HIV } \\ \text { Patients }\end{array} & \begin{array}{c}\text { Patients } \\ \text { with viral } \\ \text { coinfection }\end{array} & \text { Control } \\ \text { MDA }(\mu \mathbf{m o l} / \mathbf{L}) & 0.9 \pm 0.1 & 0.86 \pm 0.1 & 1.1 \pm 0.2 & 1.7 \pm 0.2 & 0.38 \pm 0.2 \\ \text { SOD }(\mathbf{U} / \mathbf{m L}) & 75.0 \pm 2.0 & 77.0 \pm 1.0 & 70.0 \pm 2.0 & 66 \pm 3.0 & 99.0 \pm 5.0 \\ \text { TNF- } \boldsymbol{\alpha}(\mathbf{p g} / \mathbf{m l}) & 4.0 \pm 0.2 & 3.9 \pm 0.2 & 4.1 \pm 0.1 & 4.7 \pm 0.1 & 2.6 \pm 0.2 \\ \text { AFB Z/N test } & \text { Negative } & \text { Negative } & \text { Negative } & \text { Negative } & \text { Negative } \\ \text { Plasmodium test } & \text { Negative } & \text { Negative } & \text { Negative } & \text { Negative } & \text { Negative }\end{array}$

MDA: Malondialdehyde; TNF- $\alpha$ : Tumor necrosis factor alpha; SOD: Superoxide dismutase; AFB: Acid Fast Bacilli; HCV: Hepatitis C virus; HBV: Hepatitis B virus; HIV: Human immuno deficiency virus 
Table 2: Comparative analysis of plasma MDA, SOD and TNF- $a$ obtained in the subjects.

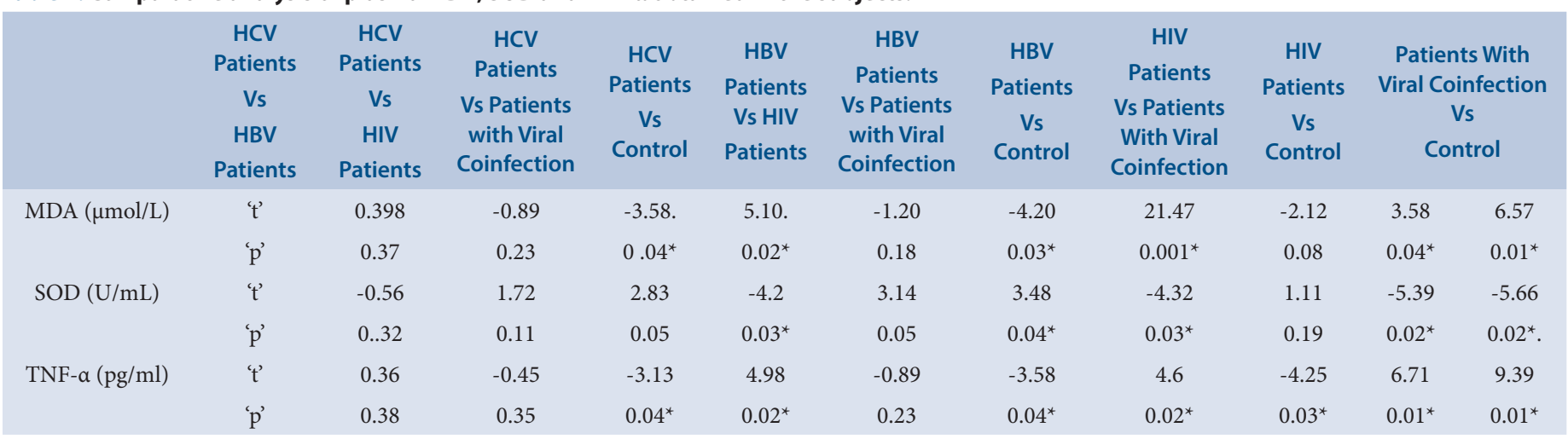

$P<0.05$ is considered to be statistically significant

MDA: Malondialdehyde; TNF- $\alpha$ : Tumor necrosis factor alpha; SOD: Superoxide dismutase; HCV: Hepatitis C virus; HBV: Hepatitis B virus; HIV: Human immuno deficiency virus

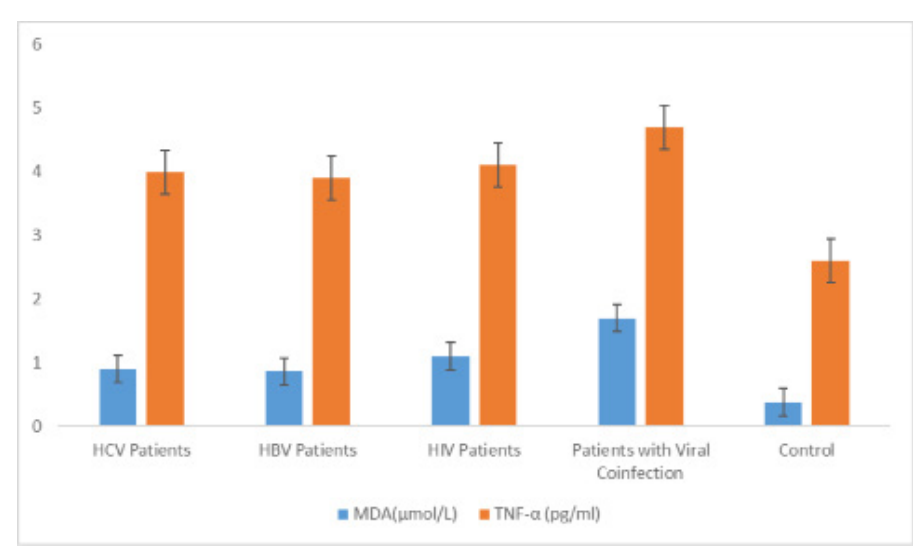

Figure 1: Comparative description of plasma MDA, and TNF-a obtained in the subjects

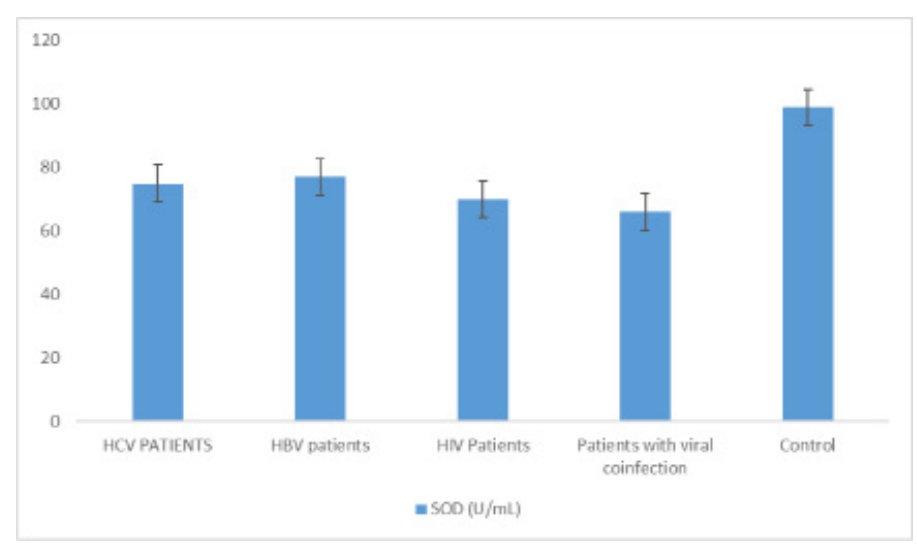

Figure 2: Comparative description of plasma SOD obtained in the subjects

\section{DISCUSSION}

Our present findings suggest a significant rise in plasma Malondialdehyde (MDA) in patients with viral co-infection compared with control and patients with mono-infections of HCV, HIV and HBV. MDA is an indirect indicator of oxidative stress In humans, oxidative stress is thought to be involved in infection, possibly through the use of reactive oxygen species by the immune system as a way to attack and kill pathogens. ${ }^{[11]}$ In a previous report oxidative stress was linked with the pathogenesis of $\mathrm{HCV}$ infection. ${ }^{[12]}$ Our finding matches with previous work. Previously Levent et al. have analyzed RBC MDA and SOD in HCV patients ${ }^{[13]}$ while we have estimated the same in serum. Moreover we have also analyzed SOD and TNF $\alpha$ in serum. Similarly in previous studies, De Maria et al. and Levent et al. had ${ }^{[13,14]}$ analyzed only HCV infection while we have also done the analysis in HIV and HBV patients and in patients with viral co-infection which was not done before.

There was a significant decrease in plasma superoxide dismutase (SOD) in patients with viral co-infection compared with control and patients with mono-infection of HBV, HIV and HCV compared to control subjects. This result can be associated with the fact that $\mathrm{SO}$ ) is a potent antioxidant whose plasma level decreases in oxidative stress. ${ }^{[15]}$ Superoxide Dismutase (SOD) is an enzyme that catalyses the dismutation of superoxide into oxygen and hydrogen peroxide, consequently providing protection against superoxide which is one of the most common free radicals in the body in oxidative stress. ${ }^{[15]}$ Superoxide is a reactive oxygen species generated by the immune system to kill invading microorganisms. In phagocytes, it is produced in large quantities by the enzyme NADPH oxidase for use in oxygen-dependent killing mechanisms of invading pathogens. ${ }^{[15]}$ Decreased SOD in viral infections in this work might be caused by increase in the production of reactive oxygen species. Furthermore, it has also been reported that viral infection like hepatitis $\mathrm{C}$ virus (HCV) may cause oxidative stress in infected cells. ${ }^{[16]}$

There was a significant increase in plasma TNF- $\alpha$ in patients with viral co-infection compared with control and patients with mono-infections of HCV, HIV and HBV. These findings is consistent with the fact that TNF- $\alpha$ is a proinflammatory cytokine whose level increases in inflammation such as in viral hepatitis. Its level increases in viral infections too to inhibit viral replication and bring about inflammatory process. It has been reported that viral hepatitis such as hepatitis $\mathrm{C}$ virus (HCV) may generate oxidative stress in infected cells as patients with chronic hepatitis $\mathrm{C}$ can express increased production of tumor necrosis factor- $\alpha$ $(\mathrm{TNF} \alpha)$, a cytokine that can produce oxidative stress by stimulating the generation of reactive oxygen species (ROS). ${ }^{[16]}$

The findings of this work indicated that the significant changes in oxidative stress and inflammatory biomarkers were more in viral coinfection. This is consistent with the report that $\mathrm{HIV} / \mathrm{HCV}$ coinfection is associated with increased oxidative stress and decreased plasma antioxidant co ncentrations compared with HIV monoinfection. ${ }^{[17]}$ 


\section{CONCLUSION}

The work revealed a significant evidence of systemic responses to viral pathogens as indicated by increased plasma malondialdehyde, tumor necrosis factor alpha and decreased plasma superoxide dismutase in viral mono and coinfections.

\section{Acknowledgement}

Authors acknowledged the supports of the Health practioners, participants and Staff of Federal Medical Centre, Owo in sourcing out subjects and for the review including the approval of the proposal of this work.

\section{CONFLICT OF INTEREST}

The authors declare that they have no conflicts of interest.

\section{ABBREVIATIONS}

ROS: Reactive Oxygen Species; MDA: Malondialdehyde; TNF- $\boldsymbol{\alpha}$ : Tumor Necrosis Factor Alpha; SOD: Superoxide Dismutase; HCV: Hepatitis C Virus; HBV: Hepatitis B Virus.

\section{REFERENCES}

1. Nathan C, Shiloh MU. Reactive oxygen and nitrogen intermediates in the relationship between mammalian hosts and microbial pathogens. Proc Nat Acad Sci. 2000;97(16):8841-8.

2. Nair $\mathrm{V}$, O'Neil CL, Wang PG. Malondialdehyde. Encyclopedia of Reagents for Organic Synthesis. John Wiley and Sons, New York. 2008.

3. Joseph N, Zhang-James Y, Perl A, Faraone SV. Oxidative Stress and ADHD: A Meta-Analysis. J Atten Disord. 2015;19(11):915-24.

4. Hayyan M, Hashim MA, AINashef IM. Superoxide Ion: Generation and Chemical Implications. Chem Rev. 2016;116(5):3029-85.
5. Swardfager W, Lanctôt K, Rothenburg L, Wong A, Cappell J, Herrmann N. A meta-analysis of cytokines in Alzheimer's disease. Biol Psych. 2010;68(10):930-41.

6. Locksley RM, Killeen N, Lenardo MJ. The TNF and TNF receptor superfamilies: Integrating mammalian biology. Cell. 2001;104(4):487-501.

7. Dowlati Y, Herrmann N, Swardfager W, Liu H, Sham L, Reim EK, et al. A meta-analysis of cytokines in major depression. Biol Psych. 2010;67(5):446-57.

8. Victor FC, Gottlieb AB. TNF-alpha and apoptosis: Implications for the pathogenesis and treatment of psoriasis. J Drugs Dermatol. 2002;1(3):264-75.

9. Weiser, Jeffrey N. The Battle with the Host over Microbial Size. Current Opinion in Microbiology. 2013;16(1):59-62.

10. Cheesbrough M. District Laboratory Practice in Tropical Countries Part 2. $2^{\text {nd }}$ Ed. Cambridge University Press. 2006.

11. Segal AW. How neutrophils kill microbes. Annu Rev Immunol. 2005;23:197-223.

12. Kaya $S$, Sütüçü $R$, Cetin ES, Aridogan BC, Aktütrk O, Delibas N. The relationship between viral load and malondialdehyde and antioxidant enzymes in patients with hepatitis C virus infection. Mikrobiyol Bul. 2006;40(1-2):55-61.

13. Levent G, Ali A, Ahmet A, Polat EC, Aytaç C, Ayse E, et al. Oxidative stress and antioxidant defense in patients with chronic hepatitis $C$ patients before and after pegylated interferon alfa-2b plus ribavirin therapy. J Transl Med. 2006;4(1):25.

14. DeMaria N, Colantoni A, Fagiuoli S, Liu GJ, Rogers BK, Farinati F, et al. Association between reactive oxygen species and disease activity in chronic hepatitis $\mathrm{C}$. Free Radic Biol Med. 1996;21(3):291-5.

15. Valko M, Leibfritz D, Moncol J, Cronin MTD, Mazur M, Telser J. Free radicals and antioxidants in normal physiological functions and human disease. Int $J$ Biochem Cell Biol. 2007;39(1):44-84.

16. Larrea E, Beloqui O, Muñoz-Navas MA, Civeira MP, Prieto J. Superoxide dismutase in patients with chronic hepatitis $C$ virus infection. Free Radic Biol Med. 1998;24(7-8):1235-41.

17. Baum MK, Sales S, Jayaweera DT, Lai S, Bradwin G, Rafie C, et al. Coinfection with hepatitis $\mathrm{C}$ virus, oxidative stress and antioxidant status in HIV-positive drug users in Miami. HIV Med. 2011;12(2):78-86

Cite this article: Olaniyan MF, Ojediran TB, Olayinka GS. Evidence of Systemic Responses to Viral Pathogens using Malondialdehyde, Tumor Necrosis Factor Alpha and Superoxide Dismutase. Int J Clin Exp Physiol. 2020;7(1):18-21. 